\title{
Changing the Narrative Language of Prosperity in Africa: A Pentecostal Hermeneutical Challenge
}

\author{
Marius Nel \\ marius.nel@nwu.ac.za
}

\begin{abstract}
Pentecostals' central theme in proclamation and practice since the beginning of their movement is holistic healing and wellbeing, resulting from what they term the "Full Gospel". At first, it did not include a prosperous lifestyle. However, a new emphasis on prosperity since the 1980s characterized a part of the African independent church movement with affinities to Pentecostal worship practices, designated as the Neo-Pentecostal movement. The research question for this article is why the narrative language of prosperity within the Pentecostal context changed in Africa and how the damages that it caused can be reversed, and the answer is found in hermeneutical challenges and solutions.
\end{abstract}

Keywords: Prosperity teaching, Pentecostal hermeneutics, neo-Pentecostalism, African independent church movement, E.W. Kenyon

\section{Introduction}

The research problem statement is that Neo-Pentecostal prosperity teaching impairs the faith life of adherents, and to understand it, requires that one should examine its narrative language in hermeneutical terms. The narrative language of prosperity explains why prosperity is included in the atonement and salvation which were brought by the cross of Christ. The teaching is not in line with Pentecostalism's Full Gospel message. The narrative language of prosperity changed in Africa within the Pentecostal context for hermeneutical reasons related to later Pentecostalism's acceptance of a pseudo-fundamenta- 


\section{Marius Nel}

list hermeneutic. In reconsidering prosperity teaching, one needs to read it in terms of a hermeneutic, characterized by Christocentric and pneumatocentric emphases that Pentecostal scholars have developed since the 1970s.

The research outcomes are relevant for systematic theological, missiological, and practical theological endeavors.

\section{Early Pentecostal Hermeneutics}

Early Pentecostals shared a Christocentric emphasis, presenting Christ as the solution to the human problem of sin and the destruction and brokenness that it carried into the world. They proclaimed that Christ brought atonement and salvation for the individual, that includes holiness, health, and prosperity ${ }^{1}$. The essence of their gospel was that Christ was revealed as Savior, Spiritbaptizer, Sanctifier, Healer, and coming King (Lewis 2003:1-25; Nel 2007:526-527). The Christocentric emphasis represents the proprium of classical Pentecostal theology, the element which specifically distinguishes the movement from other related and similar theologies. It also leads necessarily to a pneumatocentric focus because the Spirit of Christ reveals Christ exclusively.

This gospel claims freedom from sickness and suffering, based on Christ's death on the cross. The essential human predicament is sinfulness and the resultant separation from God. The purpose of Christ's death was to bring wholeness to human beings, of which a restored relationship with God is the precondition, and that also realizes in healing and holiness. Pentecostals taught that the gospel glorifies God by saving sinners from a certain eternal death and adds that divine healing and God's provision in our daily needs as conditions for wellbeing, keep on glorifying God in believers' lives (Maddocks 1990:7).

A part of Protestantism accepts a cessationist viewpoint, presupposing that God's immediate involvement with humankind through the Spirit ceased somewhere at the end of the $1^{\text {st }}$ century with the death of the last apostle and eyewitness of Jesus' ministry. It leaves no room for any further revelations of the Spirit, including signs, wonders, and other miracles. Pentecostals, however, presupposed a continuationist perspective that expects

1 The words use the same root, in wholeness, health, healing, and holiness (KabatZinn 2012:74). 
God to reveal himself continuously to believers. They read the Bible with the expectation that the same God who revealed his power and grace to people in Israel and through Christ to the early church, is still working among them. They believed that the Bible presents explanations of what God did and still wants to do in the lives of contemporary people and nations (Mashau \& Kgatle 2019).

The earliest Pentecostals used a hermeneutical approach that can be described in terms of four aspects (Moore 1987:12-13). First, they viewed the Bible as a living word that interprets the believer's life in undetermined ways, resulting in life transformation. Second, they believed that when a believer stood in a relationship with God, it would lead to a biblically informed epistemology, mediated through experiences with God. Their epistemology was based on Scripture and practical experience. Third, they read the Bible democratically: Any believer may testify how they interpret the Bible as reflected in their encounter with God (Moore 1995:12-23; cf. also McQueen 2009). Interpreting the Bible, requirs the anointing of the same Spirit that had guided the biblical writers. Finally, the church provides a corrective influence to discern truth and prevent heresy through believers being equipped with the gift of discernment (cf. 1 Cor 12:10).

Although they agreed that each believer might interpret the Bible in terms of its common sense as fundamentalists also did, they added that the core of truth lies in life-transforming encounters with God that (also) occurred when reading the Bible (Martin 2013:59-60). This formed the core of their identity (Johns 1995:75). They shared a pre-critical reading strategy with their predecessors, the Wesleyan Holiness and Keswickian movements, that adapted the proof-text method (Archer 2004:62). Proof-texting assumes that the Bible is equally inspired throughout (Archer 2004:64). They strung together scriptural passages on a specific topic without paying much attention to the text's historical and social contexts. They read the Bible without consulting any commentaries and believed that there was only one correct interpretation of the Bible $^{2}$. Their reading strategy, determined by their praxis, was pneumatic, experiential, and focused on historical narratives (Arrington 1988:382-383; cf. also Oliverio 2012:43). It allowed Pentecostals to read into Isaiah 52:13-53:12 that healing was included in the benefits of

2 This perspective eventually led to numerous disputes and factions among Pentecostals. 


\section{Marius Nel}

the cross (referring to Isaiah 53:4, Surely he has borne our infirmities and carried our diseases and by his bruises we are healed).

\section{Pentecostal Hermeneutics since the 1940s}

The early belief that all one needs to interpret the Bible was the anointing of the Spirit, changed since the 1940s, when Pentecostals realized their need for (some kind of) theological training. Coincidentally, they cooperated with Evangelicals in an attempt to shake off their sect status, accepting in part the Bible reading methods and hermeneutics of the conservative Evangelicals. In the process, they employed a pre-critical, and in some senses, a fundamenttalist hermeneutic (Cargal 1993:170), creating a hybrid between Evangelicalism and Pentecostalism (Oliverio 2012:85), with a particular Pentecostal flavor (Archer 2017:186).

However, this hermeneutic differs from fundamentalism in that fundamentalists held a cessationist view while their experience of Spirit baptism led Pentecostals to expect a supernatural intervention, as discussed above. Fundamentalists viewed the closed canon of the Bible as the authority to establish truth, while Pentecostals left room for continued charismatic revelations, implying a more open view of canonicity.

The common consensus among Pentecostal scholars about the prevailing Bible reading practices was that Pentecostals read the text in a literal way, rejecting any historical-critical readings. Their readings were experience-based, implying that they used their existential situation as a hermeneutical lens through which they read the Bible. Their purpose was not to gain information by reading the Bible; they instead listened to its message, viewed as a "word of God", relevant to the current situation. Spiritual experience played a vital role in the way that they interpreted the Bible, forming their Vorverständnis. They expected to encounter the God that biblical people had experienced. They were not interested only in a cerebral understanding of biblical history, ideas, and context, but read the Bible pragmatically, looking for application and resultant life transformation. They believed that the Spirit helped them in interpreting the text. The scopus and focus of their reading was Jesus Christ. At the same time, the Bible in its final, canonical form exercised authority over their lives. They interpreted the 
text confessionally, using the metanarrative of the history of salvation as their hermeneutical key (Anderson 2001:223; Archer 2012:173).

Since the 1970s, as one of the results of the development of Pentecostal scholarship, scholars developed a new Pentecostal hermeneutical angle ${ }^{3}$. They attempted it in terms of what they considered as essential to Pentecostalism, as stated by early Pentecostals: Spirit baptism, the exercise of the charismata and the fivefold (or fourfold) Full Gospel. Today, one finds a tension in the Pentecostal movement between a fundamentalist and Pentecostal hermeneutics. Most members and pastors probably support the first, while scholarship supports the more recent hermeneutic. In the last part of the article, this hermeneutical perspective is applied to the African Neo-Pentecostal prosperity teaching.

\section{Neo-Pentecostals and Prosperity Teaching}

A 2006 Pew Research survey asked Pentecostal participants in various African countries if they think God would "grant material prosperity to all believers who have enough faith" (Pew Research 2006:10). Of the Kenyan Pentecostals, 85 percent, of the South African Pentecostals, 90 percent, and 95 percent of the Nigerian Pentecostals affirmed the statement (Phiri \& Maxwell 2007:24). Kalu (2009:73) observes that the prosperity gospel is expanding faster than Islam in Africa, at twice the rate of the Roman Catholic Church, and at three times that of the other non-Catholic religious traditions. Gifford (2004:23-24) calls it a paradigm shift amidst the new developments

3 Vondey divides the history of Pentecostal scholarship into five periods, where each period focused on the formation of a particular vocation: The first was the period of missionaries who established training schools and Bible institutes in the 1920s and 1930s. They were followed by historians, related to the work of Walter Hollenweger in the late 1960s. Since the 1970s, biblical scholarship developed and shaped a distinctive Pentecostal hermeneutic in response to both liberalism and fundamentalism. A fourth development was the emergence of constructive theological research in the 1990s. In the last 20 years, the expansion of Pentecostal scholarship into the human and natural sciences encouraged Pentecostals to enter scientific careers explicitly as Pentecostals (Vondey 2013:122-125). In recent years, there has been an explosion of Pentecostal theological scholarship, with various theological monograph series being published by important publishers as well as a number of journals (Cartledge 2014:254). 


\section{Marius Nel}

in African Christianity. Prosperity teachers buy large expanses of land and construct facilities such as auditoriums, schools, guest houses, dormitories, banks, hospitals, and petrol stations, thereby changing the landscape of cities - they concentrate mostly on cities (Kgatle 2017).

Bafford (2019:1) remarks that prosperity theology functions within the context of "charismatic" worship services led by a "prophet" or "prophetess". They claim to have a special connection to and stand in a unique relationship with God. They perceive themselves as from a different order than their adherents, making them practically unchallengeable. Adherents have become clients of a particular "man/woman of God" (they are mostly males) (Gifford 2007:22). The clients attribute their blessings not so much to God as to the anointed "man/woman of God".

The prosperity message in African Neo-Pentecostalism incorporates several traditions and consists of a culturally mediated adaptation of imported theology. It synthesizes American materialism that defines a standard of living, characterized by profligate consumption that makes self-worth dependent on status symbols of wealth, a value compatible to the aspirations of the new African elite of rich entrepreneurs ${ }^{4}$. At the same time, African Neo-Pentecostalism also utilizes African spirituality that emphasizes the wellbeing of the holistic person. Its success motif adapts to the African traditional religious imagination of fertility, abundance, and wholeness. It contextualizes Christianity as a religion of prosperity in a poor and marginalized Africa (Gifford 2007:24). The question remains as to what extent it represents syncretism.

Mbewe (quoted in Hinn 2019:158) calls the prosperity gospel the United States" "number one export" to Africa. He opines that prosperity theology was mainly imported to Africa via Nigeria, after originating in mega-churches in the USA. However, Nigeria added their own flavor to it by imbricating it with African traditions before being exported across Africa (Mbewe 2011) ${ }^{5}$. For this reason, the indigenization of the prosperity gospel

4 In this respect, Moltmann (2001) criticises the "Western standard of living" and warns that it can only be sustained at the expense of others, including the people in the so-called Third World, coming generations, and the earth.

5 Nigerian, Ghanaian, and Kenyan preachers began to visit South Africa in the 1990s, after the dismantling of apartheid. The ideas of a new Pentecostalism began to take off among black South Africans. It put a new emphasis on black 
appeals to the traditional African spirituality and worldview. The Neo-Pentecostal pastors are, in effect, the modern witchdoctors, offering deliverance from situations that cause distress, such as a failure to attract a suitor for marriage childlessness - a significant challenge in many African marriages mental and bodily sickness, and unemployment, according to Mbewe (2011). Africans do not challenge prosperity teachers who abuse their adherents, which is an age-old African tradition of not speaking out against a powerful sangoma or chief.

The message also appeals especially to Africa's upwardly mobile youth for various reasons. Asamoah-Gyadu (2012:66) provides some of these reasons: The movement has an imaginative charismatic leadership and worship services characterized by an exuberant worship style and a dress code that is fashion-conscious. It is also supported by the innovative appropriation of modern media technologies.

Neo-Pentecostals' teaching of prosperity shares the Pentecostals' emphases on Jesus Christ as the Savior, Spirit baptizer, Sanctifier, and Healer. However, their realized eschatology differs from Pentecostals because they do not emphasize Christ as coming King to the same extent. For them, the realization of the kingdom of God is on earth with the establishment of wellbeing for believers. Because both groups share so much of what is substantial in common that guarantees a kinship between them, it is clear that the two groups should cooperate in an ongoing dialogue (Horn 1989: 117).

What distinguishes prosperity theology from Pentecostal theology can be described as its proprium, which is found in a specific emphasis on faith as a guaranteed mechanism at the believer's disposal. Faith promises to make believers healthy, wealthy, and victorious because the atonement brought healing and prosperity. Isaiah 53:4-5 explains that the suffering servant would bear humanity's infirmities and carry their diseases when he would be wounded in their stead to bear their transgressions, being crushed for their iniquities (Nel 2020a:70-90). Neo-Pentecostals view Christ as ful-

consciousness and dignity and for that reason became an attractive alternative to the option which was presented by white Charismatics, preaching about the realization of the African dream of prosperity for black people (Anderson 2005:71). 


\section{Marius Nel}

filling this prophecy, implying that believers would become free, whole, and healed through his suffering.

However, they go further by designing faith formulas that guarantee that the prophet's promises would certainly be realized in the lives of contemporary believers. It consists of the practice of positive confessions based on the belief in the applicability of those promises. In the process, it affects God's sovereignty, changing the biblical God into a deistic and manipulable god and, in continuation of an element of Eastern Orthodox Christian tradition, deify believers. Fickett (1984:8) argues for the irony of such faith formulas because prosperity teachers' god is active and alive and intervenes in and for the sake of the interest of believers, while their hidden theology implies something completely different. The faith formulas serve to manipulate and use the presumed rules and principles which are laid down by a deistic god. A living and personal relationship with a revealing God, as Pentecostals believe, is unnecessary. Their god's word limits the god to act only according to "what the Bible says". McConnell (1988:42) argues convincingly that such a god is no god at all: The term "god" is used for the impersonal "force" that characterizes metaphysical cults 6 and a "slavish puppet of anybody that knows the 'formulas' and 'spiritual laws' of how to control him". The faith formulas and laws in the faith movement are nothing more than recycled New Thought ${ }^{7}$ metaphysics (cf. also Comaroff \& Comaroff 2004:42).

Kenyon's thoughts represent a combination of Pentecostal spirituality and New Thought with the addition of the mind thought ideas and healing developed by Phineas Parkhurst Quimby, the Neoplatonic theory of correspondence found in the writings of Swedish mystic Emmanuel Swedenborg, the philosophical idealism of Ralph Waldo Emerson, the Christian Science of Mary Baker Eddy, and the theosophism of Helena Blavatsky (Nel 2000b:50).

Neo-Pentecostal independent churches that originated from the 1970 s, centered around prominent figures that operated as prophets and apostles in the tradition of a recycled Kenyon (Nel 2020b:146). The churches eventually formed part of the network movement with its new approach to the

6 Lewis (1975:4) defines a cult as a religious movement that distorts the central message of Christianity by an additional revelation.

7 New Thought groups are Religious Science, Christian Science, and the Unity School of Christianity. 
ministry and authority of the apostle that is viewed in nearly the same light as the Roman Catholic pope, with an authoritarian governance system.

It is important to note that some of the metaphysical elements that characterize prosperity teaching were evident among certain leaders during the early years of the Pentecostal movement. Two such prominent leaders were Charles Parham, a predecessor of the Azusa Street Mission, and John Lake who established the Apostolic Faith Mission in South Africa and influenced the later Zionist movement within the African Indigenous Churches movement. It should, however, also be noted that both of these leaders were evangelists and their message was emphasized by statements that generalized some truths. For instance, Lake preached that God would heal all sick believers in any given situation. According to his writings, many people testified to their receiving healing under his ministry. Later in life, his message was tempered with the reality of illness that plagued him and other believers, and his new, more realistic (and biblical) view of healing left room for God's mystery in meeting with human beings. Many other Pentecostals also taught that the atonement of Jesus brought healing on the same level as the forgiveness of sins. Over time, they shifted their teaching when they realized that, although all people who accepted the work of the cross were restored in their relationship with God, not all of them were healed in equal terms.

Healing evangelists, operating on the fringes of classical Pentecostalism since the 1950s, tried to "restore" the Pentecostals" absolutized emphasis on healing. They asserted that no Spirit-filled believers should or could be ill. The Spirit could not co-exist with an illness that comes from the devil. They taught that believers should not accept any form of illness in their bodies. They should struggle to regain their healing by practicing their faith. Those healing evangelists served as forerunners of the prosperity movement, which added prosperity to the list of benefits that are gained in and guaranteed by the process of atonement, in the same absolutist manner as the forgiveness of sins and the charismatic gifts of healing and holiness.

As stated above, prosperity teachers took over most of the elements that characterized the Pentecostal proclamation, but they radicalized some of these elements, like wholeness and healing, which were essential to their view of salvation. They also taught that faith in God's promises would determine their lives and that health, financial success, prosperity in business, and profession and success in all relationships were guaranteed because of 


\section{Marius Nel}

God's promises. Believers needed to learn to confess their faith in these promises, "claiming" them for their lives. Salvation included being saved from sin, unholiness, bodily and mental illness, poverty, material losses, and distress. Their definition of faith and how it operates, differed from the Pentecostals, who traditionally emphasized faith in terms of a child-like trust that God would provide in his own way (Horn 1989:70).

The breach that exists between prosperity teachers and classical Pentecostals is based on the unorthodox ministry style of prosperity teachers, their emphasis on divine prosperity as an absolute part of the will of God for all believers, their extraordinary fundraising methods of "sowing", and their strong emphasis on divine healing without exception (Horn 1989:5).

\section{Reasons for the Popularity of the Prosperity Gospel in Africa}

One might suspect that the prosperity gospel would not work equally well in affluent societies such as the USA and poor societies such as Africa and the rest of the global South. People living in a prosperous environment would try to realize their desire to share in the riches by believing a gospel that provides a quick and easy recipe to prosperity, by giving more and more to sow, and reap prosperity. However, the prosperity message received an extensive and receptive market in Africa $^{8}$. Its popularity can be ascribed to several factors. The first reason is found in the prosperity teaching that poverty is a curse on humanity, due to the first people's sin of disobedience to God and the demonic powers' attempts to undermine the good of God's creation. For that reason, no believer should be poor because God wants to break that curse, and believers would, as a result, always experience good health and great wealth. When Jesus died on the cross, he changed the curse of Satan, sin, and poverty into a blessing. The biblical promise to overcome the curse of poverty and share in God's wealth is for believers to contribute to the ministries of the prophets and apostles. People who pay tithes to God so that

8 For instance, David Oyedepo's Living Faith Church Worldwide Inc., better known as Winners Chapel and founded in Lagos in 1983, has 400 branches in Nigeria and can be found in 40 African countries. Its facility in Lagos seats 50,400 people. The network's leading pastors tend to be Nigerians, all fiercely loyal to Oyedepo (Gifford 2007:21). 
there is food in God's house, are blessed (cf. Mal 3:8-11), while people who disobey God by not paying their tithes, are robbing God ${ }^{9}$.

The further reason for prosperity theology's popularity may be found in the manipulative behavior of some teachers who get rich at the expense of their loyal adherents. They are guilty of manipulative coercion to finance their lavish lifestyles at the expense of the poor (Nyirenda 2018:119). Essien (2018) agrees and observes that the prosperity teaching in Africa shows a significant correlation with psychological manipulation. Adherents of prosperity preachers give from their poverty in the hope that God would reward them. For that reason, it has become critical that prosperity teachers who are responsible for the welfare of their followers, should be subjected to the evaluation of good ethical practices, and Pentecostals may help them in this process because of their history of ethical abuses in the healing ministry (Essien 2018:61).

Pastors who enjoy excessive wealth exhibited in helicopters, expensive cars, penthouses, and designer clothes, should be held accountable by their colleagues and other church institutions. When these leaders are not willing to subject themselves or their ministries' financial earnings to financial scrutiny, their behavior should be judged by others ${ }^{10}$. The church in Africa is responsible for the welfare of the extreme poor in a context where people die from hunger. This is already happening to some extent. Schliesser (2014) finds that some Neo-Pentecostal churches are emerging as more effective agents of change than secular NGOs. This practice should be extended to include all churches, including the prophet-led groups. On a conti-

9 It is important to notice that the context for the reference to tithing in Malachi 3:10-11 is the chastisement of Israel because their hearts had grown cold toward God, demonstrated when they envied the evil ways of the surrounding nations' lives. They had turned away from God's ordinances. For that reason, they presented animals at the temple as sacrifices only so that God could repay them with wealth. Their motives were wrong. Many Israelites could not bring their animals with them due to the distance from the temple and they capitalized it to pay their tithes. Because many of them forsook the temple practice, many Levites had to turn to farming to sustain themselves. The prophet is reiterating the original instructions given to Moses (Ntui-Abung 2017:47).

10 In South Africa, the ANC government is considering legal ways to normalize such pastors' financial gains through their ministries through the Commission for Religious and Linguistic Rights. 


\section{Marius Nel}

nent where millions of people are without job opportunities or prospects of acquiring a job, prosperity teachers claim that it is these people's fault that they find themselves in such dire circumstances. Their lack of belief is the cause of their mishaps. Umoh's observation is correct that it is irresponsible to blame people who experience their situation as hopeless (Umoh, quoted in Mashau \& Kgatle 2019). Instead, these leaders should consider taking coresponsibility to create an entrepreneurial climate and invest in projects that generate job opportunities. Then the church will become involved in challenging the triple unholy alliance of poverty, unemployment, and inequality (Mashau \& Kgatle 2019). At the same time, these churches should continue to provide for the most urgent needs of poor people, as many other churches do.

Mbugua (2015:66) argues that another reason why prosperity teaching is popular is because it taps into the most basic of human desires. However, he adds that the solution it offers is unbiblical, misleading, and ultimately detrimental because it leaves many of its adherents discouraged, disillusioned, and bitter when the promised rewards of the prosperity message do not realize in their lives. Another reason for its popularity is its effective indigenizing and Africanizing of the gospel. Many Africans perceived that missionary Christianity was too cerebral and non-experiential, while African religions are essentially "spiritual" religions that protect one from hostile spiritual forces (Taylor 1963:21-22). Poverty is sometimes interpreted as due to the influence of evil spirits.

Kgatle (2017) argues that Africa provides the perfect context for a dangerous co-dependent relationship between leaders of prosperity theology and their followers. Leaders find widespread poverty accompanied by the fear of slipping deeper or back into hardship. Accompanying absolute poverty is ignorance, a lack of education, and feelings of meaninglessness, hopelessness, and desperation. In parts of Africa, social institutions have collapsed, and public systems and services have become defunct because of widespread corruption and state plundering. This is especially true of the African countries in which the prosperity message had the most significant impact, like Nigeria, Kenya, Cameroon, Ghana, the Ivory Coast, Uganda, and South Africa, being afflicted by poverty and disease. They struggle with high unemployment rates and political instability. There is a limited access to medical assistance and care for the poor, partly due to state capture, plun- 
dering, and state debt ${ }^{11}$. Many of their citizens only find some comfort and succor in spirituality, while the paradise of wealth and prosperity depicted by prosperity teaching becomes attractive to many (Kingsbury \& Chesnut 2018). Gifford (2007:22-23) states that in countries in Africa where the prosperity message is popular, a dysfunctional political culture supports some leaders and officials to appropriate wealth that they do not have to account for, at the expense of the poor. The prosperity gospel seldom confronts the dysfunctional political structure because they ascribe success and blessings exclusively to God's response to their manipulative actions (cf. Bangura 2017: 249).

The last reason for its popularity is the utilization by Africans of the "Big Man" or chief syndrome (see above). Gifford (2007:23) calls it the curse of Africa and finds it in successful prosperity preachers with great wealth and lavish lifestyles at the expense of adherents, living in misery and poverty.

\section{New Pentecostal Hermeneutics: Evaluating Prosperity}

In evaluating the African prosperity message, one needs to consider several practical and theological issues. The practical issues are considered before discussing the latter with its wide-ranging hermeneutical implications.

\section{Practical Considerations}

The prosperity movement's practices are for public consumption, but it is argued that it should revisit its social views of poverty and its varied causes while also taking care not to compromise with manipulative conservative politicians. A new generation is interested in and gets enthusiastic about participating in a project with public, world-changing implications, and NeoPentecostalism is ideally situated to involve them in imaginative community projects that tackle poverty issues. Second, Neo-Pentecostalism's idea of permanent apostleship with nearly absolute powers that disempowers adherents, robs the adherents of the opportunity to practice their charismata (Dube 2014:2 of 7 pages). The same is true when apostles and prophets claim the

11 Currently, about 315 million sub-Saharan Africans live on less than a US dollar a day, while one in three Africans suffers malnutrition and the average life expectancy throughout the continent is 41 years (cf. SOS Children's Villages n.d.). 


\section{Marius $\mathrm{Nel}$}

exclusive right to interpret scriptures in terms of their exclusive access to revelation knowledge - it disempowers others to interpret the Bible.

Further, its new models for financing expensive ministry outreaches and leaders' lavish lifestyles become problematic when individuals take financial decisions without oversight from established bodies. It has led to various financial abuses that necessitate finding new financial models of financial oversight. Nyirenda (2018:98-106) also warns that some prophets teach that God would miraculously supply for believers' daily needs without referring to biblical requirements of a sound moral work ethic. Instead, Africans should be taught that God honors hard work, dedication, creativity, and perseverance by providing for people's daily needs.

When poverty is a curse on humanity due to sin and demonic powers' influence, prosperity theology teaches, it implies that no believer should be poor. It ignores widespread unemployment, requiring a more realistic evaluation of African economic woes. In light of ecological concerns, the prosperity message's unqualified consumerism, its leaders' lavish lifestyles that serve as models for their adherents, and a salvation theology that asserts that poverty is caused exclusively by the existence of evil spirits in this-worldly structures, should also be reconsidered (Nel 2020b:216). Affluence and consumerism that lead to an over-utilization of natural resources, contribute to reducing the earth to a warehouse of natural resources and raw materials (Golo 2013:376).

When religion is limited to wealth accumulation, it leads to an obsession with acquiring wealth, disqualifying one to use a kingdom perspective to prioritize the finances which are needed for ministries (AsamoahGyadu 2009:41). Christians should instead take the lead in developing the African continent with its enormous resources, waiting to be tapped in a responsible and ecologically viable manner by emphasizing the values of hard work, entrepreneurialism, perseverance, honesty, and endurance (Nyirenda 2018:135-136). Finally, Neo-Pentecostalism's practices and rituals might be contributing to the degrading of African women. Presumably, it uncritically accepts and supports traditional patriarchy and abuse female adherents by manipulation, cultural violence, financial exploitation, stringent control measures for members, coercive practices, and power abuse when women's contributions are restricted to demeaning tasks. According to Khanyile (2016), women may not serve in leadership positions within the oppressive and saliently "draconian nature" of Neo-Pentecostal spaces. 


\section{Theological Considerations}

Theological considerations include that one should investigate the hermeneutical angle of prosperity teaching. The challenge is not primarily concerned with elements in the teaching, but it is submitted, although in the way in which a part of the movement views the Bible, as the literal word of God, with every text being interpreted on the same level as all the other texts. It teaches that the Bible contains no contradictions or human mistakes, as fundamentalism also does. Understanding this, does not require a complex academic analysis or exegesis or knowledge about the original languages. The Bible should instead be read at face value and in a commonsense manner, in a way that ignores its literary, social, economic, political, and ideological contexts. Statements in the Bible should be interpreted literally, except in allegories, parables, poetry, or other literary instruments. The lack of theological training of many of the teachers support their literal fundamentalist interpretation of texts, rejection of critical thinking, and participation in harmful actions (as in the case of snacking on snakes; the spraying of insecticides in people's faces; coercing people to consume petrol, Dettol [a disinfectant], grass, live rats, and ants; fondling people's private parts, and ordering congregants to take off their clothes) (Pollitt 2015).

The epistemology of the prosperity message is the doctrine of "revelation knowledge", a term coined by Kenyon, in distinction from "sense knowledge" (Kenyon 1942:11). It is deduced from the Bible that selectively applies a few references without referring to the context of the passages. Revelation knowledge is transcendent, ultra-sensory, and supra-sensory, and exists in the realm above sense knowledge (Kenyon 1942:20). It is concerned with supernatural knowledge of God and the spiritual realm revealed in the Bible, enabling human beings to transcend the limitations of sense knowledge and act in faith (McConnell 1988:102). Prosperity teaching uses revelation knowledge as the means to interpret the Bible - it forms its hermeneutical angle.

Prosperity epistemology consists of a dualism that distinguishes one's knowledge of God as distinct from and mutually exclusive of all other kinds of knowledge. This knowledge is anti-rationalist and contains the classification of believers into classes or categories - a sectarian element that should be resisted by all means (cf. e.g., the discussion of Gnosticism and the dangers of its classification by Bultmann 1964:692-696). It bases revelation knowledge on the spiritual and divine as its origin and the human as a "spirit 


\section{Marius Nel}

being" with a devaluated body. Only the "spirit human" can receive revelation directly from the Holy Spirit. "Spirit people" are the only people who can understand the Bible correctly. The Bible does not contain such a dualistic view of revelation. Biblical revelation and salvation contain both spiritual and physical elements (McConnell 1988:108).

Revelation knowledge results in the idea that one can receive perfect knowledge from God because it supplements what one finds in the Bible about God: "It goes without argument that God has the ability to give us exact knowledge in regard to spiritual things" (Kenyon 1970:167). When prosperity teachers claim that they have discovered the way to a perfect knowledge of God, they confess in fact that their deistic god can be comprehended in terms of specific laws or principles according to which their god operates. They read the Bible in terms of these principles and interpret it to serve their theological (and monetary) interests. When human beings apply these laws, their god is compelled to react in the prescribed way as described in the Bible (actually, read into the Bible by the hermeneutical process that characterizes prosperity theology).

The prosperity gospel intends to transform the human being into a god with its concept of identification that asserts that believers can, in part, overcome their inherent tendency towards sin through personal identification with various aspects of Christ's redemptive act (Kenyon 1968; 1969): "Spirit people" can be incarnated and deified (McConnell 1988:114); and "This is how He wants you to think about yourself" (Chris Oyakhilome, quoted in Ntui-Abung 2017:17). Before the Fall, human nature was divine, but then became demonic, making Satan a god that rules creation by legal right. It implies a dualism of God and the devil, regarded as about even, although God enjoys a slight advantage over the evil forces. To recapture creation, God had to pay a ransom to the devil, requiring Jesus to die a spiritual and physical death. This is clearly not a biblical teaching, but a presumptuous overstepping of boundaries that do not allow the room that the sovereign God deals with each case according to his will ${ }^{12}$.

Presumption is the sin of bold, courageous people who, in their eagerness to accomplish great things, overstep the boundaries and claim

12 To do justice, not everyone in the prosperity movement teaches a selfish doctrine of prosperity. Some warn against the dangers of greed and the powerful hold that money can get on a person (Bangura 2017:243). 
falsely that they have received a revelation from God (Farah 1980:21). Prosperity's faith is an overstepping of boundaries without honoring or trusting God by the claim that God honors his "promises". However, when a believer holds God captive to promises found in the Bible, they manipulate a god different from the sovereign Lord, whom no one can manipulate.

Prosperity's image of God is alluring because it closely represents Western values of individualism, materialism, self-centeredness, and an urge to search for all pleasures. It depicts a God that exists for humankind's exclusive pleasure and benefit. It does not distinguish between needs and wants or desires (McConnell 1988:175) and degrades the poor by claiming that their poverty results from their dishonoring of God. Prosperity's god represents the aspirations of successful and rich Africans, not frustrated and hopeless unemployed and poor Africans.

A positive aspect of the prosperity teaching is its emphasis on holistic salvation, emphasizing healing and health as essential elements for one's physical wellbeing. Liberation from malevolent spiritual forces - an essential element of African spirituality - requires the church's involvement in a responsible and inclusive health ministry, especially in a world which is characterized by the pandemics of HIV and AIDS and Covid-19. The holistic ministry should include its investment in the ministry of deliverance and also in preventative medical care and vaccination, teaching a healthy and sober lifestyle, and the extension of health care to rural areas.

The last remark is that Christians are not to pay tithes according to the Melchizedek priesthood (He 5:6, 10; 6:20; 7:11, 15, 17, 21; 1 Pe 2:5-9). The New Testament does not contain specific regulations concerning tithing, while the early church's teaching about financial donations is mostly concerned with taking care of the poor and impoverished people.

\section{Synthesis}

It was argued that Pentecostals, since the 1940s have accepted a hermeneutic aligned with conservative Evangelicals, with some fundamentalist features that viewed the Bible in its entirety literally as the word of God. They read it without considering its historical and social context and the cultural differences that co-determine its meaning. They did not acknowledge that the Bible was written in ancient languages that pose many challenges to translators or 


\section{Marius Nel}

that the cultural world and customs which are portrayed in it, differ in many respects from contemporary times. Most Pentecostals and Neo-Pentecostal prosperity teachers use this hermeneutic to read and interpret the Bible. It is suggested that prosperity theology should reconsider its narrative language of prosperity within the African world of unemployment and financial woes of millions of people. Its teaching should be revisited with another hermeneutical paradigm that does not interpret the Bible in a literalist manner.

Its affinity with classical Pentecostalism invites Neo-Pentecostals to look closely at the Pentecostal hermeneutic which was developed by scholars in conjunction with early Pentecostal sentiments. Its Full Gospel's emphasis on Christ and the related pneumatocentric implications focus away from the benefits that the gospel supposedly promises to believers about the revelation

of God in Christ, as actualized in the fulfilment of the Spirit. Believers find their life's purpose in the charisma as a consequence of Spirit baptism that coopts them to take the gospel to the ends of the earth. The church is primarily a missiological institution that exists for the sake of the salvation of the earth. In contrast, prosperity theology is concerned with the interests of the individual believer at the cost of the world.

\section{References}

Anderson, A.H. 2001. African reformation: African initiated Christianity in the $20^{\text {th }}$ Century. Trenton: Africa World Press.

Anderson, A.H. 2005. New African initiated Pentecostalism and Charismatics in South Africa. Journal of Religion in Africa 35, 1: 66-92.

Archer, K.J. 2004. A Pentecostal hermeneutic for the twenty-first century: Spirit, Scripture, and community. London: T. \& T. Clark.

Archer, K.J. 2012. Pentecostal biblical interpretation. In Whitt, R.K. \& F.L. Arrington (eds.): Issues in contemporary Pentecostalism. Cleveland: Pathway.

Archer, K.J. 2017. Spirited conversation about hermeneutics: A Pentecostal hermeneut's response to Craig Keener's Spirit hermeneutics. Pneuma 39: 179-197.

Arrington, F.L. 1988. Hermeneutics, historical perspectives on Pentecostal and Charismatic. In Burgess S.M. \& G.B. McGee (eds.): Dictionary 
of Pentecostal and Charismatic movements. Grand Rapids: Zondervan.

Asamoah-Gyadu, J.K. 2009. Did Jesus wear designer robes? Christianity Today November 2009: 38-41. URL: https://www.christianitytoday. com/ct/2009/november/main.html

Asamoah-Gyadu, J.K. 2012. Learning to prosper by wrestling and by negotiation: Jacob and Esau in contemporary African Pentecostal hermeneutics. Journal of Pentecostal Theology 21: 64-86. doi: 10.aa63.174552512x633303

Bafford, D. 2019. The Prosperity Gospel and an unprosperous reality in postapartheid South Africa: Conservative Evangelical responses to Charismatic Christianity. Paper presented at the Wits Interdisciplinary Seminar in the Humanities, Wits Institute for Social and Economic Research, University of the Witwatersrand, Johannesburg, on March 4, 2019.

Bangura, J.B. 2017. Charismatic movements, state relations and public governance in Sierra Leone. Studies in World Christianity 23, 3: 237256.

Bultmann, R. 1964. Ginosko. In Kittel, G. \& G. Friedrich (eds.): TDNT. Bromiley, G.W. (trans.). Grand Rapids: William Eerdmans.

Cargal, T.B. 1993. Beyond the Fundamentalist-Modernist controversy: Pentecostals and hermeneutics in a postmodern era. Pneuma 15, 2: 163-187.

Cartledge, M.J. 2014. Pentecostal theology. In Robeck, C.M. \& A. Young (eds.): The Cambridge Companion to Pentecostalism. New York: Cambridge University Press.

Chicago Statements. n.d. Section 23: The Chicago statements on biblical inerrancy and hermeneutics. Available at: http://www.danielakin. com/wp-content/uploads/old/Resource_545/Book\%202,\%20Sec\% 2023.pdf. (Accessed on April 26, 2021.)

Comaroff, J. \& J.L. Comaroff 2004. Privatising the millennium: New Protestant ethics and spirits of capitalism in Africa and elsewhere. In Chidester, D., A. Tayob \& W. Weisse (eds.): Religion, politics, and identity in a changing South Africa. Münster: Waxmann.

Dube, M. 2014. Between the Spirit and the word: Reading the gendered African Pentecostal Bible. HTS Teologiese Studies/HTS Theological Studies 70, 1.7 pages. doi: http://dx.doi.org/10.4102/hts.v70i1.2651 
Essien, E.D. 2018. Ethical audit of Prosperity Gospel: Psychological manipulation or social ministry. International Journal of KnowledgeBased Organisations 8, 2: 53-66. doi: 10.4018/IJKBO.2018040105

Farah, C. 1980. From the pinnacle of the temple: Faith or presumption? Plainfield: Logos International.

Fickett, J.D. 1984. Confess it, possess it: Reflection on faith-formula theology. Oklahoma City: Presbyterian and Reformed Renewal Ministries.

Gifford, P. 2004. Ghana's new Christianity: Pentecostalism in a globalising African economy. Bloomington: Indiana University Press.

Gifford, P. 2007. Expecting miracles: The Prosperity Gospel in Africa. Christian Century 10 July 2007: 20-24.

Golo, B.K. 2013. Africa's poverty and its Neo-Pentecostal "liberators": An ecotheological assessment of Africa's prosperity gospellers. Pneuma 35: 366-384. doi: 10.1163/15700747-1234166

Hinn, C.W. 2019. God, greed, and the (Prosperity) Gospel: How truth overwhelms a life built on lies. Grand Rapids: Zondervan.

Horn, J.N. 1989. From rags to riches: An analysis of the faith movement and its relation to the classical Pentecostal movement. Pretoria: UNISA Press.

Johns, J.D. 1995. Pentecostalism and the postmodern worldview. Journal for Pentecostal Theology 7: 73-96.

Kabat-Zinn, J. 2012. Mindfulness for beginners: Reclaiming the present moment...and your life. Boulder: Sounds True.

Kalu, O.U. 2009. A discursive interpretation of African Pentecostalism. Fides et Historia 41, 1: 71-90.

Kenyon, E.W. 1942. The two kinds of knowledge. Seattle: Kenyon's Gospel Publishing Society.

Kenyon, E.W. 1968. Identification: A romance in redemption. Seattle: Kenyon's Gospel Publishing Society.

Kenyon, E.W. 1969. What happened from the cross to the throne. Lynnwood: Kenyon's Gospel Publishing Society.

Kenyon, E.W. 1970. The hidden man: An unveiling of the subconscious mind. Seattle: Kenyon's Gospel Publishing Society.

Kgatle, M.S. 2017. The unusual practices within some Neo-Pentecostal churches in South Africa: Reflections and recommendations. HTS 
Teologiese Studies/HTS Theological Studies 73, 3. 8 pages. doi: https://doi.org/10.4102/hts.v73i3.4656

Kingsbury, K. \& A. Chesnut 2018. How Catholics are falling for the Prosperity Gospel. Catholic Herald. November 29, 2018. Available at: $\quad$ https://catholicherald.co.uk/magazine/the-liturgy-of-money/. (Accessed om March 30, 2021.)

Khanyile, S.B. 2016. The virtualisation of the church: New Media representations of Neo-Pentecostal performance(s) in South Africa. MA dissertation, Graduate School of Humanities School of Social Sciences Department of Sociology, University of the Witwatersrand, Johannesburg.

Lewis, G.R. 1975. Confronting the cults. Grand Rapids: Baker Publication Group.

Lewis, P.W. 2003. Reflections of a hundred years of Pentecostal theology. Cyberjournal for Pentecostal-Charismatic Research 12: 1-25. URL: http://www.pctii.org/cyberj/cyberj12/lewis.htm\#_ftn1 Maddocks, M. 1990. The Christian healing ministry. $2^{\text {nd }}$ ed. London: SPCK. Martin, D. 2013. Pentecostalism: An alternate form of modernity and modernisation? In Hefner, R.W. (ed.): Global Pentecostalism in the $21^{\text {st }}$ century. Bloomington: Indiana University Press.

Mashau, T.D. \& M.S. Kgatle 2019. Prosperity Gospel and the culture of greed in post-colonial Africa: Constructing an alternative African Christian theology of Ubuntu. Verbum et Ecclesia 40, 1.8 pages. doi: https://doi.org/10.4102/ve.v40i1.1901

Mbewe, C. 2011. A letter from Kabwata. Nigerian religious junk! February 20, 2011. Available at: http://www.conradmbewe.com/2011/02/ nigerian-religious-junk.html. (Accessed on March 22, 2021.)

Mbugua, K. 2015. Suffering. In Maura, M.O., C. Mbewe, K. Mbugua, J., Piper, \& W. Grudem (eds.): Prosperity? Seeking the true gospel. Nairobi: Africa Christian Textbooks.

McConnell, D.R. 1988. A different gospel: A bold and revealing look at the biblical and historical basis of the word of faith ministries. Peabody: Hendrickson.

McQueen, L.R. 2009. Joel and the Spirit: The cry of a prophetic hermeneutic. Rev. ed. Cleveland: CPT. 
Moltmann, J. 2001. The destruction and healing of the earth. In Stackhouse, M.L. (ed.): God and globalization: The Spirit and the modern authorities. Harrisburg: Trinity Press International.

Moore, R.D. 1987. A Pentecostal approach to Scripture. Seminary Viewpoint 8, 1: 12-13.

Moore, R.D. 1995. Deuteronomy and the fire of God: A critical Charismatic interpretation. Journal of Pentecostal Theology 3, 7: 11-33.

Nel, M. 2007. Pentecostals' reading of the Old Testament. Verbum et Ecclesia 28, 2: 524-241.

Nel, M. 2020a. Isaiah 53 and its use in the New Testament and classical Pentecostal churches in Southern Africa. Australasian Pentecostal Studies 21, 1: 70-90.

Nel, M. 2020b. The Prosperity Gospel in Africa: An African Pentecostal hermeneutical consideration. Eugene: Wipf \& Stock.

Ntui-Abung, J. 2017. The chaos of the Prosperity Gospel: A case study of two prominent Nigerian pastors. Bloomington: WestBow Press.

Nyirenda, T.J. 2018. Misconceptions of healing, blessings and miracles. Scotts Valley: CreateSpace.

Oliverio, L.W. 2012. Theological hermeneutics in the classical Pentecostal tradition: A typological account. Global and Pentecostal Studies 12. Leiden: Brill.

Pew Research. 2006. Spirit and power: A 10-country survey of Pentecostals. Available at: https://www.pewresearch.org/wp-content/uploads/sites /7/2006/10/pentecostals-08.pdf. (Accessed on April 26, 2021.)

Phiri, I. \& J. Maxwell 2007. Gospel riches: Africa's embrace of prosperity Pentecostalism provokes concern - and hope. Christianity Today July 2007: 23-29.

Pollitt, R. 2015. Religion: We don't need no regulation. Maverick Life. August 14, 2015. Available at: https://www.dailymaverick.co.za/ article/2015-08-14-religion-we-dont-need-no-regulation/. (Accessed on April 26, 2021.)

Schliesser, C. 2014. On a long neglected player: The religious factor in poverty alleviation: The example of the so-called "Prosperity Gospel" in Africa. Exchange 43, 4: 339-359.

SOS Children's Villages. n.d. On the poorest continent, the plight of children is dramatic. SOS Children's Villages. Available at: https://www.sos- 
usa.org/about-us/where-we-work/africa/poverty-in-africa. (Accessed on March 21, 2021.)

Taylor, J.V. 1963. The primal vision: Christian presence amid African religion. London: SCM Press.

Vondey, W. 2013. Pentecostalism: A guide for the perplexed. London: Bloomsbury.

\author{
Prof Marius Nel \\ Research Professor
}

Pentecostalism and Neo-Pentecostalism

Faculty of Theology and Religion North-West University's Potchefstroom campus

E-mail: marius.nel@nwu.ac.za 